\title{
Seed morphology of Vriesea friburgensis var. paludosa L.B. Sm. (Bromeliaceae) ${ }^{1}$
}

\author{
Jenny Paola Corredor Prado ${ }^{2}$, Eder Carlos Schmidt ${ }^{3}$, Douglas André Steinmacher ${ }^{4}$, Miguel Pedro Guerra ${ }^{2}$, \\ Zenilda Laurita Bouzon ${ }^{3}$, Lírio Luiz Dal Vesco ${ }^{5}$ and Rosete Pescador ${ }^{2,6}$
}

Received: 27.02.2013; accepted: 21.05.2014

\begin{abstract}
Seed morphology of Vriesea friburgensis var. paludosa L.B. Sm. (Bromeliaceae)). The Brazilian Atlantic Forest is a biodiversity hotspot, and bromeliads are omnipresent in this biome. This study was aimed at characterizing both morphological and histochemical aspects of Vriesea friburgensis var. paludosa L.B. Sm. seeds. The seeds are filiform with a brown seed coat and yellowish-colored plumose appendages. Seeds are typically $4.4 \mathrm{~mm}$ long, $0.5 \mathrm{~mm}$ wide, and 1000 seeds weigh $683.8 \mathrm{mg}$. The seed coat presents phenolic compounds. Starch represents the main reserve compound in the endosperm; however, it is also present in smaller amounts in the embryo. The embryo occupies one-third of the seed and has a zone of constriction in the hypocotyl-radicle axis. The results of this work will contribute to the overall biology of $V$. friburgensis var. paludosa, as well as its taxonomic delimitation.
\end{abstract}

Keywords: anatomy, embryo, endosperm, histochemistry, seed coat

RESUMO - (Morfologia da semente de Vriesea friburgensis var. paludosa L.B. Sm. (Bromeliaceae)). A Mata Atlântica é um hotspot de biodiversidade, e as bromélias são um grupo taxonômico bastante comum presente neste bioma. O objetivo deste estudo foi caracterizar os aspectos morfológicos e histoquímicos das sementes Vriesea friburgensis var paludosa L.B. Sm. As sementes são filiformes, com tegumento marrom e apêndices plumosos amarelados. Têm valores médios de 4,4 mm de comprimento, 0,5 mm de largura, e peso de 1.000 sementes de 683,8 mg. O tegumento apresenta compostos fenólicos. O amido é o principal componente de reserva no endosperma, porém ele também se apresenta em menores quantidades no embrião. O embrião ocupa um terço da semente e apresenta uma zona de constrição no eixo hipocotilo-radicula. Os resultados do presente trabalho contribuem na biologia e na delimitação taxonomia de $V$. friburgensis var. paludosa.

Palavras-chave: anatomia, embrião, endosperma, histoquímica, tegumento

\section{Introduction}

The Atlantic Forest biome contains high biodiversity and species endemism, and it is among the 25 hotspots on the planet (Myers et al. 2000). As far as plant diversity is concerned, the group of bromeliads plays an important role on this forest (Stehmann et al. 2009). The Bromeliaceae family includes 58 genera and 3172 species and subspecies (Luther 2008). It preferentially occurs in the tropics, ranging from North to South America, with a single species occurring in Africa, Pitcairnia feliciana (Benzing 2000). The Brazilian Atlantic Forest has a large number of representatives from the Bromeliaceae family, with an estimated occurrence of 816 species, out of which $651(80 \%)$ are endemic (Stehmann et al. 2009).

Recent phylogenetic analyses divided the Bromeliaceae family into eight subfamilies, Brocchinioideae, Lindmanioideae, Tillandsioideae, Hechtioideae, Navioideae, Pitcairnioideae, Puyoideae and Bromelioideae (Givnish et al. 2007). The subfamily Tillandsioideae is characterized by capsuletype fruits and seeds with plumose appendages adapted to wind dispersal (Smith \& Downs 1977, Givnish et al. 2007). Vriesea is the second largest genus in the subfamily Tillandsioideae, which is

1. Parte da Dissertação de Mestrado da primeira Autora

2. Programa de Pós-graduação em Recursos Genéticos Vegetais, Universidade Federal de Santa Catarina, 88034-001 Florianópolis, SC, Brasil

3. Programa de Pós-graduação em Biologia Celular e do Desenvolvimento, Universidade Federal de Santa Catarina, 88049-900 Florianópolis, SC, Brasil

4. Instituto Biosomática, 13825-000 Holambra, SP, Brasil.

5. Centro de Ciências Agrárias, Universidade Federal de Santa Catarina, Campus Curitibanos, 89520-000 Curitibanos, SC, Brasil

6. Corresponding author: rosete.pescador@ufsc.br 
composed of about 260 species (Luther 2008), and in the Atlantic Forest, this genus presents the greatest richness, with approximately 166 species (Martinelli et al. 2008, Stehmann et al. 2009). However, it remains difficult to accurately determine the specific taxonomic boundaries in the Vriesea genus (Martinelli et al. 2008). Therefore, detailed morphological studies are required for a complete taxonomic circumscription of these species.

Vriesea friburgensis is a medium-sized bromeliad, reaching more than $2 \mathrm{~m}$ of height during the reproductive stage with beautiful inflorescences which provide ornamental potential (Reitz 1983). This species grows as a terrestrial plant, forming dense clusters, but it may also occur on tops of rocks and on other plants (Reitz 1983). It is found in Brazil's southern, southeastern and northeastern regions, from Rio Grande do Sul to Pernambuco States (Martinelli et al. 2008), occurring in the Atlantic Forest (Stehmann et al. 2009) (figure 1a). However, wild populations of $V$. friburgensis have been reduced by recent destruction and fragmentation of its natural habitat due to human disturbance as well as illegal collections (Paggi et al. 2013). According to Martinelli et al. (2008), the conservation status of Vriesea friburgensis is endangered and vulnerable. Such species presents two varieties which differ mainly in the architecture and inflorescence color. The tucumanensis variety is characteristic of the plateau (planalto meridional), and the paludosa variety which is characteristic of Coastal Restinga (Reitz 1983).

Studies related to seed morphology and anatomy may be helpful in clarifying the relationships amongst representatives of the Tillandsioideae family (Palací et al. 2004, Barfuss et al. 2005, Magalhães \& Mariath 2012). Moreover, according to Buckeridge et al. (2004), enhanced knowledge about the chemical composition of seeds native to tropical forests is crucial. According to the mentioned authors, such information is important to assist in the production of high quality seedlings. From this perspective, additional knowledge about the characteristics of $V$. friburgensis var. paludosa seeds could improve germination studies and provide more insight into the taxonomic characteristics of this species. The present study provides a morphological and histochemical characterization of $V$. friburgensis var. paludosa seeds.

\section{Material and methods}

Plant material - Vriesea friburgensis var. paludosa seeds were obtained from mature fruits harvested from plants grown in the bromeliad collection of the Centro de Ciências Agrárias, Universidade Federal de Santa Catarina, Brazil (figure 1b)

Morphological analysis - According to the Rules for Seed Analysis (Brasil 2009), a precision analytical balance $(0.1 \mathrm{mg})$ was used to obtain the weight of 1000 seeds. As for the biometric description, the length and width of 50 seeds were randomly selected from five different specimens and then measured with a digital caliper individually, according to the method of Silva \& Scatena (2011). These seeds were used for the viability test. The seeds were previously soaked in distilled water for $24 \mathrm{~h}$ and subsequently assessed by soaking longitudinal sections in an aqueous $1 \%$ $\left(\mathrm{w} \mathrm{v}^{-1}\right)$ 2,3,5-triphenyl-tetrazolium chloride solution (TZ) (McGoverin et al. 2011), and incubated at $25^{\circ} \mathrm{C}$ in the dark for $4 \mathrm{~h}$. The living parts of a viable seed should be stained red (Patil \& Dadlani 1993).

Scanning Electron Microscopy (SEM) - Samples with approximately $5 \mathrm{~mm}$ in length were fixed with $2.5 \%$ glutaraldehyde in $0.1 \mathrm{M}$ sodium cacodylate buffer (pH 7.2) plus $0.2 \mathrm{M}$ sucrose overnight. The material was post-fixed with $1 \%$ osmium tetroxide for $4 \mathrm{~h}$. The samples were dehydrated in ethanolic series, dried in the $\mathrm{CO}_{2}$ Critical point dryer (EM-CPD-030, Leica, Heidelberg, Germany), and then sputter-coated with gold prior to examination. The samples were examined under SEMJSM 6390 LV (JEOL Ltd., Tokyo, Japan) at 20 kV.

Confocal laser scanning microscopy (CLSM) - The samples were analyzed in a laser scanning confocal microscope (Leica TCS SP-5, Wetzlar, Germany) with Leica HCX PLAPO lambda 63×/1.4-0.6 oil immersion objective. For nuclei detection, $0.5 \mathrm{mg} \mathrm{mL}^{-1}$ DAPI (4',6-Diamidino-2-phenylindole dihydrochloride; Sigma-Aldrich, St. Louis, MO) was added to the samples during 30 minutes (Ouriques \& Bouzon 2008) and observed by using a UV light-emitting diode (peak wavelength of $405 \mathrm{~nm}$ excitation and spectrum emission of 510-566 nm). The LAS-AF Lite program (Leica) was used for final processing of the confocal images.

Light Microscopy (LM) - The samples were fixed in $2.5 \%$ paraformaldehyde in $0.2 \mathrm{M}(\mathrm{pH} 7.2)$ phosphate buffer overnight. Subsequently, the samples were dehydrated in increasing series of ethanol aqueous solutions (Schmidt et al. 2009). After dehydration, the samples were infiltrated with Historesin (Leica 
Historesin, Heidelberg, Germany). Sections $(5 \mu \mathrm{m})$ were obtained by using a manual rotational microtome (Leica model RM 2135) with tungsten blades. The sections were stained with different histochemical techniques: Toluidine Blue O (TB-O) $0.5 \%$ aqueous solution, pH 3.0 (Merck Darmstadt, Germany) in order to identify phenols and acidic polysaccharides (O’Brien et al. 1964, Gordon \& McCandless 1973); Periodic Acid-Schiff (PAS) to identify neutral polysaccharides (Gahan 1984); Lugol to identify starch grains (Johansen 1940); and Coomassie Brilliant Blue (CBB) $0.4 \%$ in Clarke's solution (Serva, Heidelberg, Germany) to identify proteins (Fisher 1968, Gahan 1984). Some sections were doublestained with PAS + CBB (Schmidt et al. 2012). As for the detection of total lipids, fresh material was used with longitudinal sections $10 \mu \mathrm{m}$ thick frozen in Microtome Cryostat (Leica CM1850 UV). Sudan Black B (SB-B) staining was used to identify lipids (Johansen 1940). Sections were analyzed with an Olympus ${ }^{\circledR}$ DP 71 camera attached to an Olympus ${ }^{\circledR}$ BX-40 microscope.

Fluorescence microscopy (FM) - Representative samples of fresh material were longitudinally cut free-hand, mounted on slides, and analyzed using a UV light-emitting diode (wavelength of $405 \mathrm{~nm}$ ) in the Epifluorescent Microscope (Olympus BX 41) equipped with the Image Capture Q Capture Pro 5.1 Software (Qimaging Corporation, Austin, TX, USA).

\section{Results}

Morphological analysis - Vriesea friburgensis var. paludosa has small seeds with yellowish-colored

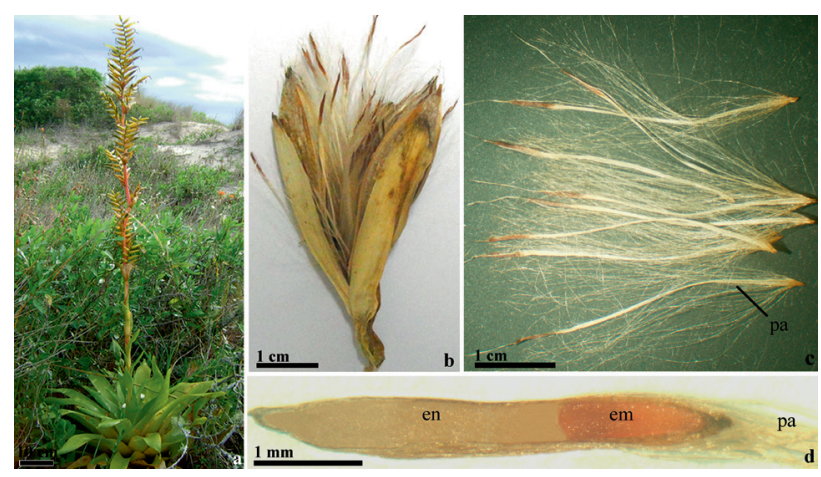

Figure 1. Morphological aspects of Vriesea friburgensis var. paludosa L.B. Sm. in the reproductive state. a. Plant in natural environment. b. Open capsules, exposing seeds. c. Seeds with plumose appendages. d. Longitudinal section of the seed submitted to tetrazolium test, showing internal structures: embryo (reddish coloring) and endosperm (colorless). pa: plumose appendage; em: embryo; en: endosperm. plumose appendages longer at the micropylar end. The plumose appendages are located at the base of the fruit (figures 1b,c). The seeds are filiform with a brown seed coat. The weight of 1000 seeds is $683.8 \mathrm{mg}$. Regardless the appendages, the average seeds measure $4.4 \mathrm{~mm}$ long and $0.5 \mathrm{~mm}$ wide (table 1 ). All the seeds evaluated were viable under tetrazolium (TZ) solution. The embryo occupies about one-third of the seed with reddish coloring, while the endosperm is colorless (figure 1d).

Microscopic analysis: Seed Coat - SEM revealed the presence of undulated anticlinal walls of Seed Coat (figure 2a). This tissue surrounds the whole seed (figure 2b, c). The seeds have both testa (outer seed coat) and tegmen (inner seed coat). The testa consists of cells with lignified walls which form the plumoses appendages. The tegmen is biseriate and composed of exo- and endotegmen. The exotegmen is formed by cells with thickened walls and without content in mature seeds (figures $2 d-h$ ). The cells of the endotegmen showed a greenish-blue color shift when stained with TB-O reagents, indicating the presence of phenolic compounds (figure 2d; table 2). For the endotegmen treated with SB-B, we have observed a slight reaction in the cytoplasm, with a pale darkish color, indicating hydrophobic radicals or lipids (figure 2e). Furthermore, the endotegmen cells were larger than other seed cells. The cytoplasm and the cell walls reacted positively to PAS, which indicates the presence of neutral polysaccharides (figure $2 \mathrm{f}$ ). Other histochemical analyzes indicated the lack of starch reserves (figure $2 \mathrm{~g}$ ) and protein compounds (figure 2h) in this tissue. Moreover, autofluorescence was observed in the seed coat, probably caused by phenolic compounds found in the endotegmen (figure 2i).

Microscopic analysis: Endosperm - The seeds are classified as albuminous. The endosperm is located mainly in the seed chalazal region and is composed of two distinct tissues: the aleurone layer and the starchy parenchyma. The aleurone layer is composed

Table 1. Average size and weight of Vriesea friburgensis var. paludosa L.B. Sm. seeds. Means followed by standard deviation $( \pm)$.

\begin{tabular}{ll}
\hline Variable & Means \\
\hline Weight of 1,000 seeds & $683.8 \mathrm{mg}$ \\
Length & $4.4 \pm 0.06 \mathrm{~mm}$ \\
Width & $0.5 \pm 0.01 \mathrm{~mm}$ \\
\hline
\end{tabular}


of a cell layer found beneath the seminal tegument in the peripheral region of the endosperm. SEM image of aleurone layer showed cellular spaces, probably from the lipid materials extracted by ethanol during the dehydration process (figure $2 b$ ). At the micropylar end of the seed, in which the embryo can be seen, the endosperm is reduced, and the aleurone layer is found on the periphery of the embryo (figure 2c). The aleurone layer cells have thick walls and vary from round to rectangular. These cells revealed the presence of acidic polysaccharides in the cytoplasm and on the cell wall by reaction to TB-O (figure $2 \mathrm{~d}$; table 2 ). In
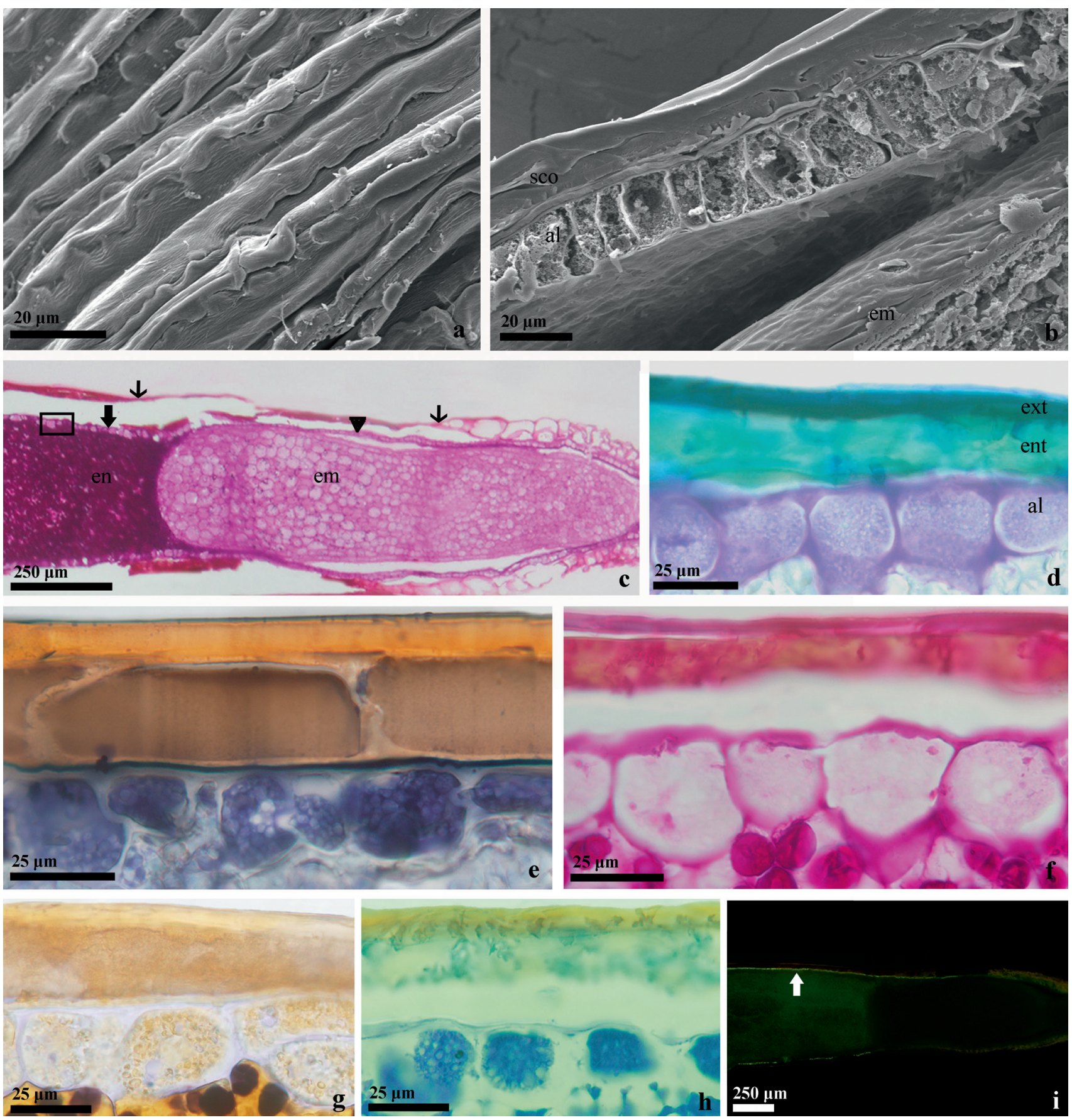

Figure 2. Seed coat and aleurone layer of Vriesea friburgensis var. paludosa L.B. Sm. seed. a-b. SEM images. c. Section submitted to PAS. Seed coat (open arrow), aleurone layer around the endosperm (black arrow) and around the embryo (arrowhead). d-h. Details of seed coat and aleurone layer (region marked with box in fig. c) under different histochemical tests: d. TB-O; e. SB-B; f. PAS; g. Lugol; h. CB-B; i. Fluorescence microscopy images. Autofluorescence caused by phenolic compounds (white arrow). al: aleurone layer; em: embryo; en: endosperm; ent: endotegmen; ext: exotegmen; sco: seed coat. 
the cytoplasm, the presence of lipids was also observed (figure 2e). The neutral polysaccharides were found primarily as cell wall constituents, indicating the presence of cellulose and/or pectin (figure $2 \mathrm{f}$ ). In these cells, no reserve compounds, such as starch (figure $2 \mathrm{~g}$ ) were identified, however CBB showed a great amount of protein bodies (figure $2 \mathrm{~h}$ ).

SEM images of endosperm showed starchy parenchyma composed of cells with high presence of starch grains of varying sizes (figure $3 a$ ). Confocal microscopy images showed the nuclei of these cells with fewer inflorescences than the cell nuclei in both aleurone layer and embryo (figure $3 b$ ). The reaction to TB-O showed the starchy parenchyma composed of several irregular cell layers with inconspicuous nuclei (figure 3c; table 2). Acidic polysaccharides were detected in the parenchyma cells, whereas the cytoplasm showed weak granulations (figure $3 \mathrm{c}$ ).
Neutral polysaccharides were also found to be cell wall constituents, indicating the presence of cellulose and/or pectin. In particular, they were found as starch grains in amyloplasts in the cytoplasm, which turned red when double-stained with PAS + CBB (figure 3d). Furthermore, we observed a conspicuous presence of protein materials in the shape of disorganized amorphous grains in the cytoplasm of cells, as identified by Coomassie blue staining (figure 3d). Conversely, just a few lipids were present (figure 3e). A complex of stacked cell walls was also observed in the endosperm, on the opposite side of the cotyledon apex along with a large amount of starch grains, whereas proteins were not detected (figures $3 f, g$ ).

Microscopic analysis: Embryo - It was possible to distinguish the uniseriate protoderm, a tenuous procambium, the cotyledon, as well as shoot and root apical meristems (figure 4a). The embryo presented

Table 2. Compounds evaluated by histochemical tests in Vriesea friburgensis var. paludosa L.B. Sm. seeds. + Positive reaction; - negative reaction; \pm weak reaction.

\begin{tabular}{|c|c|c|c|c|}
\hline Structure & Figure number & Histochemical test & Reaction & Compounds \\
\hline \multirow[t]{5}{*}{ Seed coat } & 2 & TB-O & + & Phenolic compounds \\
\hline & & SB-B & \pm & Lipids and tannins \\
\hline & & PAS & + & Neutral polysaccharides \\
\hline & & LUGOL & - & \\
\hline & & $\mathrm{CBB}$ & - & \\
\hline \multirow[t]{5}{*}{ Aleurone layer } & 2 & TB-O & + & $\begin{array}{c}\text { Acidic polysaccharides in the } \\
\text { cytoplasm }\end{array}$ \\
\hline & & SB-B & + & Lipids in the cytoplasm \\
\hline & & PAS & + & $\begin{array}{l}\text { Neutral polysaccharides in the } \\
\text { cell wall }\end{array}$ \\
\hline & & LUGOL & - & \\
\hline & & $\mathrm{CBB}$ & + & Total protein in the cytoplasm \\
\hline \multirow[t]{5}{*}{ Starchy parenchyma } & 3 & TB-O & + & $\begin{array}{l}\text { Acidic polysaccharides in the } \\
\text { cell wall, weak reaction in the } \\
\text { cytoplasm }\end{array}$ \\
\hline & & SB-B & \pm & Lipids in the cytoplasm \\
\hline & & PAS & + & $\begin{array}{l}\text { Neutral polysaccharides in the } \\
\text { cell wall and in the cytoplasm. }\end{array}$ \\
\hline & & LUGOL & + & Starch in the amyloplast \\
\hline & & $\mathrm{CBB}$ & + & Total protein in the cytoplasm \\
\hline \multirow[t]{5}{*}{ Embryo } & 4 & TB-O & + & Acidic polysaccharides \\
\hline & & SB-B & + & Total lipids \\
\hline & & PAS & + & Neutral polysaccharides \\
\hline & & LUGOL & + & Starch \\
\hline & & $\mathrm{CBB}$ & + & Proteins \\
\hline
\end{tabular}


a constriction zone between the shoot and the root portion (figure $4 \mathrm{~b}$ ). The presence of polysaccharides, proteins and lipids was identified (figures $4 \mathrm{c}-\mathrm{e}$; table 2). The starch grains could be visualized after positive reaction to PAS or Lugol (figure $4 \mathrm{f}, \mathrm{g}$ ). The apical part of the cotyledon has a smooth surface and it is immersed in the seed endosperm which fills the chalazal portion of the seed. The cotyledon cells are bigger than the other embryo cells and it is composed of a uniseriate epidermis and parenchyma cells. In parenchymal cells, the onset of procambium, which extends throughout the embryo, could be distinguished (figure 4h). Three-dimensional reconstruction in CLSM allowed visualization of the expanding cotyledon on the shoot apical meristem, covering it like a sheath.
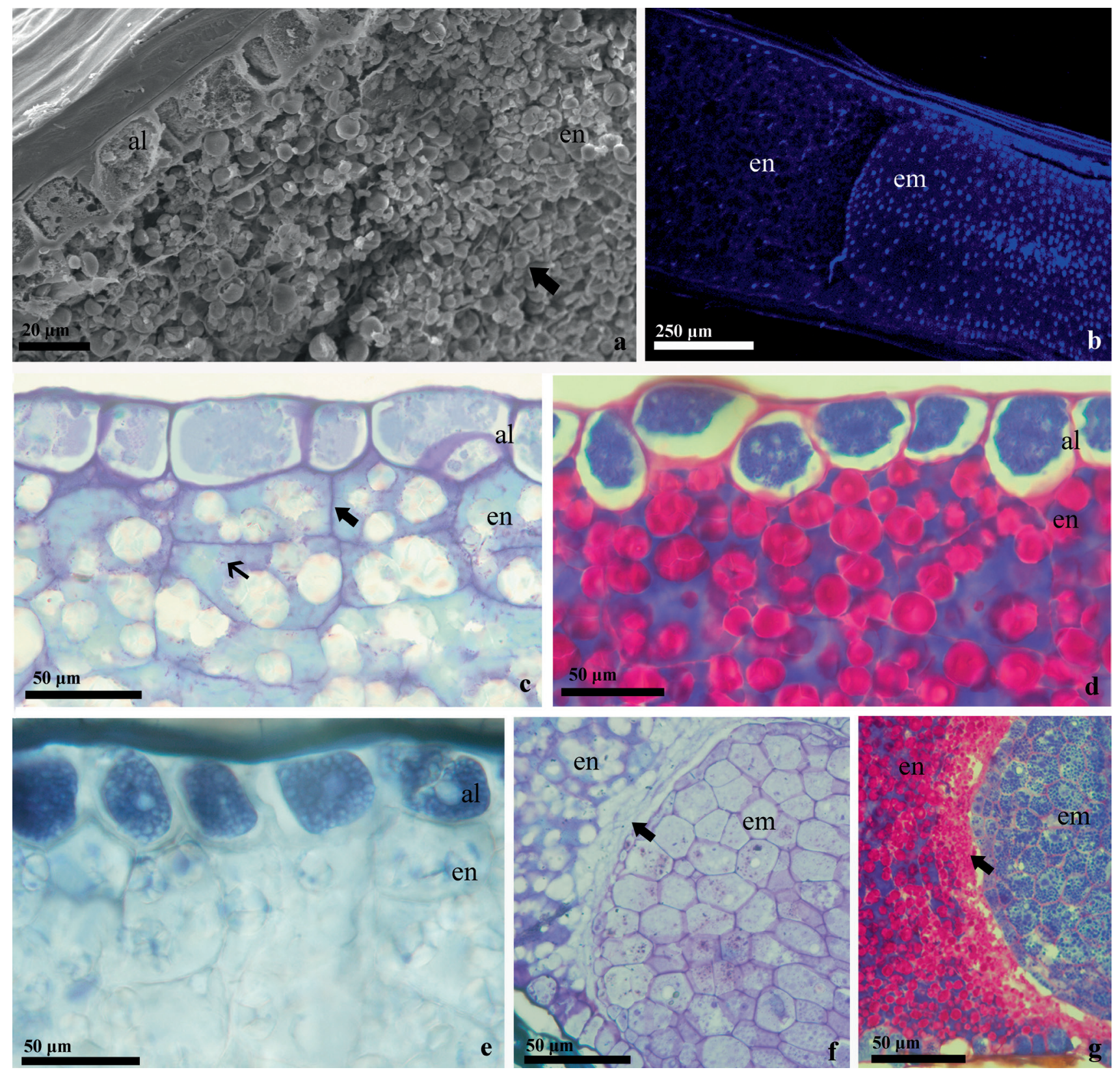

Figure 3. Longitudinal sections of the endosperm of Vriesea friburgensis var. paludosa L.B. Sm. seed. a. SEM image showing starch grains (arrow) b. Confocal microscopy image. Details of endosperm under different histochemical tests: c. TB-O showing acidic polysaccharides in the cell walls (arrow) and cytoplasm with weak acidic granulations (open arrow); d. double-stained with PAS + CB-B, indicating the red-colored starch and blue-colored proteins; e. Sudan Black B (SB-B); f. endosperm under TB-O test with cell wall complex stacked (arrow) near the cotyledon; g. same region under double-stained with PAS + CB-B, showing the absence of protein compounds, but a rather large amount of starch grains (arrow). al: aleurone layer; em: embryo; en: endosperm. 


\section{Discussion}

The data obtained from this study are similar to the morphological characteristics of the seeds found on other species of this genus (Pereira et al. 2008, Magalhães \& Mariath 2012). According to Benzing (2000) and Scatena et al. (2006), the presence of winged structures, such as plumose appendages, facilitates long-distance dispersal of seeds, enabling them to reach, as well as thrive in, inhospitable microenvironments. This type of appendage has been found on seeds of other bromeliads which represent the subfamily Tillandsioideae (Scatena et al. 2006, Pereira et al. 2008, Pereira et al. 2009, Silva \& Scatena 2011, Magalhães \& Mariath 2012). The plumose appendages of Vriesea friburgensis var. paludosa show the type of structural arrangement suggested by Magalhães \& Mariath (2012) for the genus Vriesea: the exoand mesotesta are split in the chalazal region, while remaining attached to each other in the micropylar region to form a parachute-like structure. According to Palaci (2004), the genus Vriesea has seed appendages of cell rows derived from longitudinal splitting of the outer integument, which strongly elongates at the base throughout seed maturation.

The tetrazolium (TZ) biochemical test is based upon the activity of the respiration enzymes in seeds. The dehydrogenase enzymes reduce the colorless tetrazolium salt solution to a chemical compound that stains living cells (respiring) with a red color, wheareas dead cells (not respiring) remain colorless (Elias \& Garay 2004). The areas of vital importance in interpreting the staining pattern in monocots are the shoot and root apical meristems and the portion in which the embryo is attached to the cotyledon (Patil \& Dadlani 1993). By using TZ, it was found that $V$. friburgensis var. paludosa seeds were viable, presenting embryonic coloring. However, the endosperm remained unstained due to the absence of respiratory activity in this tissue. Mature seeds of several monocot genera showed no staining in the endosperm when they were subjected to TZ (Hands et al. 2012). This coloration showed that the embryo occupied one-third of the seed. In accordance with Magalhães \& Mariath (2012), the genus Vriesea has a small embryo which occupies 27 to $33 \%$ of the seed.

The presence of the endosperm indicates albuminous seeds. The ability of the endosperm to store starch so proficiently is a characteristic associated with monocot orders, including the
Poales (Hands et al. 2012). However, the reserves accumulated in the endosperm of bromeliads vary according to the species, and the space occupied by the endosperm in the seeds can also vary according to the genus (Magalhães \& Mariath 2012). Nevertheless, the genus Vriesea is characterized by the accumulation of starch as a reserve compound (Magalhães \& Mariath 2012).

Seed coats develop from the integuments which surround the ovule and, after fertilization, can include extensive differentiation and accumulate substances that can also contribute to overall seed morphology (Moïse et al. 2005). Thus, the features observed in the seed coat of $V$. friburgensis var. paludosa determine its role in protecting the embryo and regulating germination. In the present study, the phenolic compounds were identified mainly by autofluorescence and reaction with TB-O in the endotegmen. However, according to Geier (1980), PAS also reacts with phenolic compounds when highly concentrated. In bromeliads, the endotegmen of Vriesea and Tillandsia genera is formed by cells with phenolic compounds (Magalhães \& Mariath 2012). The presence of these compounds in the endotegmen of mature seeds may be a distinctive feature of Poales (Nakamura et al. 2009). Phenolics are secondary metabolites produced by plants to defend themselves against pathogens (Freeman \& Beattie 2008). The content of phenolic compounds found in seeds may be related to the permeability of seed coats to water (Marbach \& Mayer 1974) and may restrict oxygen uptake (Bewley \& Black 1994). These compounds also cause the seed coat structure to be harder and act as germination inhibitors (Werker 1997).

According to Magalhães \& Mariath (2012) the endotesta cells of Vriesea, have irregular secondary thickening (undulations) on their anticlinal walls, and the connections between cells may be straight or slightly curved. Only curved connections between cells of $V$. friburgensis var. paludosa were observed.

In the mature seed, both the aleurone and the embryo remain alive, but they maintain a basal level of metabolic activity (Leprince et al. 1993). On the other hand, most endosperm cells die during seed maturation (Berger 1999). Some monocot species undergo programmed cell death in the endosperm without degeneration (Sreenivasulu \& Wobus 2013). Moreover, the cytoplasmic contents of the cells are replaced by the stored food reserves (Bewley \& Black 1994).

CLSM allows images with different depths and more contrast, as well as three-dimensional 
information of the sample (Martinez-Nistal 2002). DAPI identified nuclei of embryonic cells and aleurone layer in of $V$. friburgensis var. paludosa. However, the nuclei of endosperm cells were not stained probably degraded DNA in such cells. These nuclei were conspicuous under light microscopy.

Apart from its role as a reserve tissue, the endosperm of $V$. friburgensis var. paludosa could also regulate embryonic development through the provision of several cell layers opposite the apex of the cotyledon. This has been previously suggested by Cecchi-Fiordi et al. (2001) in seeds of the genus Tillandsia. Several species of the genus Vriesea also showed these layers of compressed cells (Magalhães \& Mariath 2012). According to the mentioned authors, their cell contents were consumed by the growing embryo. However, in this region, $V$. friburgensis var. paludosa presents reserve compounds such as starch. Therefore, the absence of reserve compounds in this region cannot be a characteristic of the genus Vriesea. Furthermore, the embryo of $V$. friburgensis var. paludosa showed the presence of starch. However, Magalhães \& Mariath (2012) found no starch in the embryos of several species of the genus Vriesea.

Area constriction in the radicle-hypocotyl axis of the embryo has been observed on species of genus Tillandsia (Cecchi-Fiordi et al. 1996, Morra et al. 2002, Magalhães \& Mariath 2012). According to Magalhães \& Mariath (2012), the most notable difference between the genera Vriesea and Tillandsia results from the presence/absence of that constriction zone. However, that region is present in the $V$. friburgensis var. paludosa embryo. Therefore, this feature cannot be used for the delimitation Vriesea and Tillandsia.

\section{Conclusions}

The morphological and histochemical features of seeds provide important information for an infrageneric
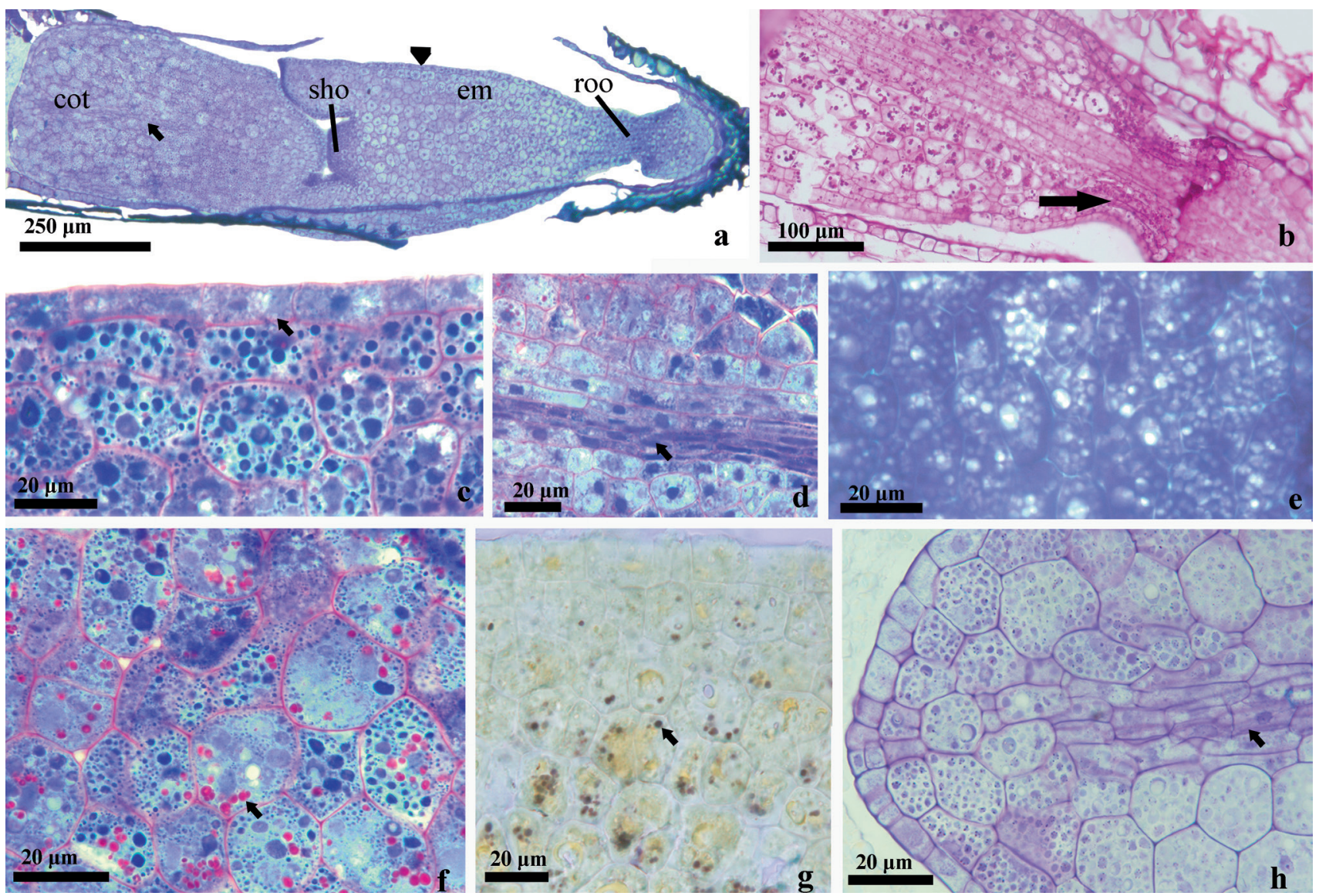

Figure 4. Longitudinal sections of the embryo of Vriesea friburgensis var. paludosa L.B. Sm. a, h. TB-O test; b. PAS; c, d, f. double-stained with PAS + CBB; e. SB-B and g. Lugol reagent. a. Structures of the embryo: protoderm (arrowhead), procambium (arrow), cotyledon, shoot and root apical meristems. b. Detail of constriction zone (arrow). c. Detail of protoderm (arrow). d. Detail of procambium elongated cells (arrow). f, g. Embryo cells with small starch grain (arrow). h. Details of cotyledon. Uniseriate epidermis and parenchyma cells with the onset of procambium (arrow). cot: cotyledon; em: embryo; sho: shoot meristem; roo: root meristem. 
delimitation of bromeliads. The knowledge gained from the present study of $V$. friburgensis var. paludosa seeds is suggestive of strategies used by this species, including the presence of plumose appendices and accumulation of phenolic compounds in the seed coat, to establish itself and survive in inhospitable microenvironments. This species has characteristics that differ from other members of the genus Vriesea. Among them are: smaller amounts of starch in the embryo and the presence of a zone constriction in the hypocotyl-radicle axis. The results of this work contribute to the overall biology of $V$. friburgensis var. paludosa, as well as its taxonomic delimitation.

\section{Acknowledgements}

The authors wish to thank Coordenação de Aperfeiçoamento de Pessoal de Nível Superior (CAPES), Conselho Nacional de Desenvolvimento Científico e Tecnológico (CNPq), Fundação de Amparo à Pesquisa do Estado de Santa Catarina (FAPESC), and Financiadora de Estudos e Projetos (FINEP) for their financial support. The authors also would like to thank the staff of the Laboratorio Central de Microscopia Electrônica (LCME), Universidade Federal de Santa Catarina.

\section{Literature cited}

Barfuss, M.H.J., Samuel, R., Till, W. \& Stuessy, T.F. 2005. Phylogenetic relationships in subfamily Tillandsioideae (Bromeliaceae) based on DNA sequence data from seven plastid regions. American Journal of Botany 92: 337-351.

Benzing, D.H. 2000. Bromeliaceae: Profile of an adaptive radiation. Cambridge University Press, New York.

Berger, F. 1999. Endosperm development. Current Opinion in Plant Biology 2: 28-32.

Bewley, J.D. \& Black, M. 1994. Seeds. Physiology of development and germination. 2 ed. Plenum Press, New York.

BRASIL. Ministério da agricultura, Pecuária e Abastecimento. 2009. Regras para análises de sementes. Secretaria de Defesa Agropecuária, Brasília.

Buckeridge, M.S., Aidar, M.P.M., Santos, H.P. \& Tiné, M.A.S. 2004. Acúmulo de reservas. In: A.G. Ferreira \& F. Borghetti (eds.). Germinação: do básico ao aplicado. ARTMED, Porto Alegre, pp. 31-50.

Cecchi-Fiordi, A., Palandri, M.R., Tani, G. \& Di Falco, P. 1996. Cytological aspects of the hypocotyl correlated to the behavior of the embryo radicle of Tillandsia atmospheric species. Caryologia 49: 113-124.
Cecchi-Fiordi, A., Palandri, M.R., Turicchia, S., Tani, G. \& Di Falco P. 2001. Characterization of the seed reserves in Tillandsia (Bromeliaceae) and ultrastructural aspects of their use at germination. Caryologia 54: 1-16.

Elias, S. \& Garay, A. 2004. Tetrazolium test (tz). A fast, reliable test to determine seed viability. Oregon State University seed laboratory, Corvallis.

Fisher, D.B. 1968. Protein staining of ribboned epon sections for light microscopy. Histochemie 16: 92-96.

Freeman, B.C. \& Beattie, G.A. 2008. An Overview of Plant Defenses against Pathogens and Herbivores. The Plant Health Instructor. DOI: 10.1094/PHI-I-2008-0226-01 (accessed 20-IV-2014).

Gahan, P.B. 1984. Plant histochemistry and citochemistry. Academic Press, London.

Geier, T. 1980. PAS-positive reaction of phenolic inclusions in plant cell vacuoles. Histochemistry 65: 167-171.

Givnish, T.J., Millam, K.C., Berry, P.E. \& Sytsma, K.J. 2007. Phylogeny, adaptive radiation, and historical biogeography of Bromeliaceae inferred from ndh $\mathrm{F}$ sequence data. In: J.T. Columbus, E.A. Friar, J.M. Porter, L.M. Prince \& M.G. Simpson (eds.). Monocots: Comparative biology and evolution - Poales. Rancho Santa Ana Botanic Garden, Claremont, pp. 3-26.

Gordon, E.M. \& McCandless, E.L. 1973. Ultrastructure and histochemistry of Chondrus crispus Stackhouse. In: M.J. Harvey \& J. Mclachlan (eds.). Chondrus crispus. Nova Scotian Institute of Science, Halifax, pp. 111-133.

Hands, P., Kourmpetli, S., Sharples, D. Harris, R.G. \& Drea, S. 2012. Analysis of grain characters in temperate grasses reveals distinctive patterns of endosperm organization associated with grain shape. Journal of Experimental Botany 63: 6253-6266.

Johansen, D.A. 1940. Plant microtechnique. 2 ed. Mcgraw Hill, New York.

Leprince, O., Hendry, G.A.F. \& Mckersie, B.D. 1993. The mechanisms of desiccation tolerance in developing seeds. Seed Science Research 3: 231-246.

Luther, H.E. 2008. An alphabetic list of Bromeliad Binomials. The Marie Selby Botanical Gardens. 11 ed. Bromeliad Society International, Sarasota.

Magalhaes, R.I. \& Mariath, J.E.A. 2012. Seed morphoanatomy and its systematic relevance to Tillandsioideae (Bromeliaceae). Plant Systematics and Evolution 298: 1881-895.

Marbach, I. \& Mayer, A.M. 1974. Permeability of seed coats to water as related to drying conditions and metabolism of phenolics. Plant physiology 54: 817-820.

Martinelli, G., Vieira, C.M., Gonzalez, M., Leitman, P., Piratininga, A., Ferreira Da Costa, A. \& Forzza, R.C. 2008. Bromeliaceae da Mata Atlântica brasileira: lista de espécies, distribuição e conservação. Rodriguésia 59: 209-258. 
Martínez-Nistal, A. 2002. Microscopía láser confocal. In: J.L. Martínez (ed.). Técnicas de imagen en biología. Universidad de Oviedo, Oviedo, pp. 1-20.

McGoverin, C.M., Engelbrecht, P., Geladi, P. \& Manley, M. 2011. Characterisation of non-viable whole barley, wheat and sorghum grains using near-infrared hyperspectral data and chemometrics. Analytical and Bioanalytical Chemistry 401: 2283-2289.

Moïse, J.A., Han, S., Gudynaitę-Savitch, L., Johnson, D.A. \& Miki, B.L.A. 2005. Seed coats: structure, development, composition, and Biotechnology. In Vitro Cellular \& Developmental Biology-Plant 41: 620-644.

Morra, L., Dottori, N. \& Cosa, M.T. 2002. Ontogenia y anatomia de semilla y fruto en Tillandsia tricholepis (Bromeliaceae). Boletin de la Sociedad Argentina de Botánica 37: 193-201.

Myers, N., Mittermeier, R.A., Fonseca, G.A.B. \& Kent, J. 2000. Biodiversity hotspots for conservation priorities. Nature 403: 853-858.

Nakamura, A.T. \& Scatena. V.L. 2009. Desenvolvimento pós-seminal de espécies de Poaceae (Poales). Acta Botanica Brasilica 23: 212-222.

O'brien, T.P, Feder, N. \& Mccully, M.E. 1964. Polychromatic staining of plant cell wall by toluidine blue. Protoplasma 59: 39-52.

Ouriques, L.C. \& Bouzon, Z.L. 2008. Organização estrutural e ultra-estrutural das células vegetativas e da estrutura plurilocular de Hincksia mitchelliae (Harvey) P.C. Silva (Ectocarpales, Phaeophyceae). Rodriguésia 59: 673-685.

Paggi G.M., Silveira L.C.T., Zanella C.M., Bruxel M., Bered F., Kaltchuk-Santos E. \& Palma-Silva C. 2013. Reproductive system and fitness of Vriesea friburgensis, a self-sterile bromeliad species. Plant Species Biology 28: 169-176.

Palací, C.A., Brown, G.K. \& Tuthill, D.E. 2004. The seeds of Catopsis (Bromeliaceae: Tillandsioideae). Systematic Botany 29: 518-527.

Patil, V.N. \& Dadlani, M. 1993. Tetrazolium test for seed viability and vigour. Disponível em http://seednet.gov. in/Material/Handbook_of_seed_testing/Chapter $\% 2014$. pdf (accessed 10-VII-2013).

Pereira, A.R., Andrade, A.C., Pereira, T.S., Forzza, R.C. \& Rodrigues, A.S. 2009. Comportamento germinativo de espécies epífitas e rupícolas de Bromeliaceae do Parque Estadual do Ibitipoca, Minas Gerais, Brasil. Revista Brasileira de Botânica 32: 827-838.
Pereira, A.R., Pereira, T.S., Rodrigues, A.S. \& Andrade, A.C.S. 2008. Morfologia de sementes e do desenvolvimento pós-seminal de espécies de Bromeliaceae. Acta Botanica Brasilica 22: 1150-1162.

Reitz, R. 1983. Bromeliáceas e a malária - bromélia endêmica. (Flora ilustrada Catarinense série 983). Herbário Barbosa Rodrigues, Itajai.

Scatena, V.L., Segecin, S. \& Coan, A. 2006. Seed morphology and post-seminal development of Tillandsia L. (Bromeliaceae) from the "Campos Gerais", Paraná, Southern Brazil. Brazilian Archives of Biology and Technology 49: 945-951.

Schmidt, E.C., Pereira B., Santos R., Gouveia C., Costa G.B., Faria G.S.M., Scherner F., Horta P.A., Paula M.R., Latini A., Ramlov F., Maraschin M. \& Bouzon Z.L. 2012a. Responses of the macroalgae Hypnea musciformis after in vitro exposure to UV-B. Aquatic Botany 100: 8-17.

Schmidt, E.C., Pereira, B., Pontes, C.L.M., Santos, R., Scherner, F., Horta, P.A., Paula, M.R., Latini, A., Maraschin, M. \& Bouzon, Z.L. 2012b. Alterations in architecture and metabolism induced by ultraviolet radiation-B in the carragenophyte Chondracanthus teedei (Rhodophyta, Gigartinales). Protoplasma 249: 353-367.

Schmidt, E.C., Scariot, L.A., Rover, T. \& Bouzon, Z.L. 2009. Changes in ultrastructure and histochemistry of two red macroalgae strains of Kappaphycus alvarezii (Rhodophyta, Gigartinales), as a consequence of ultraviolet B radiation exposure. Micron 40: 860-869.

Silva, I.V. \& Scatena, V.L. 2011. Morfologia de sementes e de estádios iniciais de plântulas de espécies de Bromeliaceae da Amazônia. Rodriguésia 62: 263-272.

Smith, L.B. \& Downs, R.J. 1977. Tillandsioideae (Bromeliaceae). In: Flora Neotropica. Monograph 14. Hafner Press, New York, v.2, pp. 661-1492.

Sreenivasulu, N. \& Wobus, U. 2013. Seed-development programs: A systems biology-based comparison between dicots and monocots. Annual Review of Plant Biology 64: 189-217.

Stehmann, J.R., Forzza, R.C., Sobral, M. \& Yoshino Kamino L.H. 2009. Gimnospermas e Angiospermas. In: J.R. Stehmann, R.C. Forzza, A. Salino, M. Sobral, D. Pinheiro da Costa, L.H. Yoshino Kamino (eds.). Plantas da Floresta Atlântica. Jardim Botânico do Rio de Janeiro, Rio de Janeiro, pp. 27-37.

Werker, E. 1997. Seed anatomy. Gebrüder Borntraeger, Berlin. 